\author{
dr hab. Dariusz KIELCZEWSKI, prof. UwB \\ Wydział Ekonomii i Finansów, Uniwersytet w Białymstoku \\ e-mail: d.kielczewski@uwb.edu.pl \\ ORCID: 0000-0001-9801-909X
}

DOI: $10.15290 / O E S .2021 .03 .105 .01$

\title{
PANDEMIA COVID-19 W PERSPEKTYWIE EKONOMII ZŁOŻONOŚCI ${ }^{1}$
}

\begin{abstract}
Streszczenie
Cel - Wskazanie, że ekonomia złożoności proponuje bardziej adekwatny opis zjawisk gospodarczych i podstawę strategii działania w walce z pandemią COVID-19 niż ekonomia tradycyjna, co może być początkiem przełomu w rozwoju nauk ekonomicznych.

Metoda badawcza - Analiza literatury przedmiotu oraz wnioskowanie dedukcyjne.

Wnioski - Przyjęcie perspektywy ekonomii złożoności w opisie zjawisk towarzyszących pandemii pozwala na wiarygodne wyjaśnienie problemów i ograniczeń polityki walki z koronawirusem oraz daje interesująca podstawę do wdrożenia strategii działania przynoszącej szansę na wykorzystanie obecnego kryzysu w celu uruchomienia procesów rozwoju gospodarczego bardziej adekwatnych do współczesnych wyzwań gospodarczych, ekologicznych i społecznych, a także do rewizji dotychczasowego dorobku nauk ekonomicznych.

Oryginalność / wartość / implikacje / rekomendacje - Artykuł jest głosem w dyskusji o ekonomicznych aspektach pandemii oraz o teorii ekonomii, stanowi też autorską interpretację tez ekonomii złożoności w kontekście problemu COVID-19.
\end{abstract}

Słowa kluczowe: pandemia COVID-19, ekonomia złożoności, ekonomia heterodoksyjna

\section{COVID-19 PANDEMIC IN THE COMPLEXITY ECONOMICS}

\section{Summary}

Purpose - An indication that complexity economics proposes a more adequate description of economic phenomena and the basis of a strategy to combat the COVID-19 pandemic than traditional economics, which may be the beginning of a breakthrough in the development of economic sciences.

Research method - Analysis of the literature on the subject and deductive reasoning.

Results - The adoption of the complexity economics perspective in the description of the phenomena accompanying the pandemic allows for a credible explanation of the problems and limitations of the anti-coronavirus policy and provides an interesting basis for an action strategy that gives a chance to use the current crisis to initiate economic development processes more adequate to contemporary economic, ecological and social challenges, and also to revise the hitherto achievements of economic science.

Originality / value / implications / recommendations - The article is a contribution to the discussion on the economic aspects of the pandemic and the theory of economics, it is also an original interpretation of the theses of complexity economics in the context of the COVID-19 problem.

1 Artykuł wpłyną 16 kwietnia 2021 r., zaakceptowano 16 czerwca 2021 r. 
Keywords: COVID-19 pandemic, complexity economics, heterodox economics

JEL Classification: B41, B52

\section{Wstęp}

Pandemia COVID-19 spowodowała głęboki kryzys gospodarczy i postawiła rządy przed wyzwaniem w postaci odbudowy gospodarki, która popadła w stan recesji. Oznacza to konieczność skonstruowania odpowiedniej strategii wychodzenia z kryzysu. Dotychczasowa połowiczność sukcesów w walce z pandemią prowokuje do pytania o to, na ile mainstreamowa ekonomia jest zdolna do wypracowania programu odnowy gospodarki, a tym samym o to, czy propozycje alternatywne wobec głównego nurtu nie stanowia bardziej atrakcyjnej podstawy dla skonstruowania skutecznej polityki. Tym samym może to oznaczać nadejście znaczących przewartościowań w nauce ekonomii. Przykładem wartościowej propozycji jest nurt określany jako ekonomia złożoności.

Celem artykułu jest wskazanie, że ekonomia złożoności proponuje bardziej adekwatny opis zjawisk gospodarczych i podstawę do wdrożenia strategii działania w walce z pandemią COVID-19 niż ekonomia tradycyjna, co może być początkiem przełomu w rozwoju nauk ekonomicznych.

\section{Istota ekonomii złożoności}

Ekonomia złożoności rozwija się od początku lat dziewięćdziesiątych XX wieku, chociaż w historii było wielu fizyków i matematyków, którzy z powodzeniem angażowali się w zagadnienia gospodarcze i finansowe. D. Bernoulli zwrócił uwagę, że jednostki, podejmując decyzje w warunkach niepewności, nie zawsze kierują się maksymalizacją zysku, ale raczej maksymalizacja oczekiwanej użyteczności, tym samym wprowadzając to ostatnie zagadnienie do analizy ekonomicznej [Maryniak, 2016, s. 2-3]. P.S. Laplace stwierdził, że wydarzenia gospodarcze, które na pierwszy rzut oka moga wydawać się przypadkowe i nieprzewidywalne, w rzeczywistości podlegaja pewnym prawom, a zatem dają się przewidzieć [Leszek, 2011]. J. Tinbergen w pierwszej połowie lat dwudziestych ubiegłego wieku studiował fizykę, a w roku 1969 otrzymał nagrodę Nobla z dziedziny ekonomii za wkład w rozwój i zastosowanie modeli dynamicznych w analizie procesów gospodarczych, co również jego pozwala uznać za prekursora tego nurtu myśli ekonomicznej.

Ekonomia złożoności ma do tej pory dość niewielką reprezentację wśród ekonomistów akademickich, choć wyraźnie przybywa zwolenników takiego podejścia głównie dlatego, że jest traktowana jako ciekawa propozycja rozwinięcia i pogłębienia założeń ekonomii głównego nurtu, a nawet jako nowy paradygmat ekonomii [Jakimowicz, 2017; Rosser, 2004]. 
Ekonomia złożoności rozpatruje obiekty ekonomiczne jako złożone systemy adaptacyjne. Są to otwarte systemy dynamiczne, które składają się z wzajemnie oddziałujących na siebie agentów i wykazują emergencję. Oznacza ona - biorąc pod uwagę dynamikę rynków i gospodarek - pewną nadwyżkę funkcjonalną ponad to, co wynika z sumy elementów składowych. Ekonomia złożoności wykorzystuje całkiem nowe metody, które przeważnie nie były wcześniej stosowane przez nauki ekonomiczne. Zaliczamy tu dynamikę nieliniową, opartą głównie na teorii chaosu deterministycznego i teorii złożoności, geometrię fraktalną, teorię bifurkacji i katastrof, procesy stochastyczne, automaty komórkowe, koncepcję krawędzi chaosu czy samoorganizację. Ponadto w naukach ekonomicznych wykorzystuje się coraz częściej metody, które zostały zaczerpnięte z fizyki statystycznej czy mechaniki kwantowej. Tak więc punktem wyjścia rozważań ekonomii złożoności jest próba zrozumienia procesów, które zachodzą w gospodarce, przy użyciu metod badawczych stosowanych w nowej fizyce [Jakimowicz, 2017]. Zwolennicy tego podejścia metodologicznego wskazują, że postęp techniczny doprowadził do szybkiego rozwoju gospodarki, a w szczególności rynków finansowych, co czyni gospodarkę coraz bardziej złożonym systemem. Przykładowo na rynku finansowym ogromna liczba podmiotów dokonuje wielu transakcji w czasie rzeczywistym, wchodząc ze sobą w bardzo skomplikowane zależności nieliniowe. I właśnie metody wykorzystywane w fizyce, takie jak analiza procesów stochastycznych, układów nieliniowych, chaosu dynamicznego czy fizyka statystyczna, umożliwiają analizę rynków w sposób ilościowy o wiele dokładniej i wszechstronniej niż obecna metodyka [Kirman, 2018, s. 155-176]. Zwolennicy ekonomii złożoności zwykle, jak wspomniano, traktują ten nurt jako nowy paradygmat ekonomiczny, łączaccy w sobie kilka nurtów ekonomii nieortodoksyjnej, przede wszystkim ekonomię behawioralną, ekonomię ekologiczną, ekonomię ewolucyjną, ekonomię eksperymentalną i ekonofizykę [Hommes, 2013; Jakimowicz, 2010; Manson, 2001; Mantegna, Stanley, 2000; Rosser, 2008].

Powyższe można przełożyć także na analize pozostałych zjawisk gospodarczych. Badanie zachowań dużych społeczności pozwala ustalić pewne regularności statystyczne. Choć pojedynczy przedsiębiorcy i konsumenci kierują się prostymi zasadami praktycznymi, starając się dostosować do otoczenia w sposób racjonalny na tyle, na ile jest to możliwe w warunkach silnego niedostatku i konkretnego zlokalizowania informacji, co ma poprawić ich sytuację, to ta wielość indywidualnych prostych decyzji przekłada się na bardzo złożoną heterogeniczną rzeczywistość gospodarczą. Jest ona systemem złożonym, w którym jednostki stanowią coś na kształt cząsteczek czy, jak to ujął A. Kirman [2018, s. 162], uspołecznionych insektów. Obrazowo ujmując gospodarkę, można metaforycznie porównać ją do mrowiska, które jest bardzo złożone, występuje w nim szereg pozornie chaotycznych nieliniowych ruchów i zależności; jednak przy wykorzystaniu odpowiednich narzędzi badawczych można sformułować pewne ogólne prawidłowości, które definiują całość. „Działania uczestników [rynku - przyp. Autora] wynikają ze stanu, w jakim się znajduja..., a ich wybory zmieniają się w kontekście wyborów sąsiadów. Taka wizja wydaje się bardziej adekwatnym ujęciem rozwoju rynków niż ta skupiona na systemie osiagającym stan równowagi tylko po to, by zostać z niej wytrąconym przez jakiś 
zewnętrzny wstrząs" [Kirman, 2018, s. 163], jak dotąd przyjmuje ekonomia głównego nurtu.

Ekonomiści złożoności krytykują założenie o niewidzialnej ręce regulującej rynek oraz koncepcje jednostki działającej w sposób racjonalny (bomo oeconomicus). Odrzucają też hipotezę efektywnego rynku, która w przypadku rynków finansowych mówi, że ceny papierów wartościowych w danej chwili odzwierciedlają wszystkie dostępne informacje na ich temat (czyli według tej hipotezy niemożliwe jest osiaganie ponadprzeciętnych zysków w długiej perspektywie, co jest sprzeczne z danymi empirycznymi). Wymarzony przez ekonomistów głównego nurtu stan równowagi uważa się za metodologiczny mitonem, niemający związku z realnym światem procesów gospodarczych, którego cechą jest dynamika i zmienność. Stan równowagi pochodzi raczej z platońskiego świata nieruchomych i niezmiennych idei, a nie z realnego materialnego świata [Orrell, 2010]. Proste, ale oderwane od rzeczywistości idee równowagi i liniowości powinny być zastapione przez bardziej złożone podejście systemowe, z wykorzystaniem metod, które wypracowała fizyka na przestrzeni ostatnich dziesięcioleci.

Dla ekonomii głównego nurtu charakterystyczne jest podejście liniowe. Relacja między zmiennymi jest bardzo prosta. Efekt jest zależny od bodźca - jest do niego wprost proporcjonalny. Zmiana bodźca oznacza jednakową zmianę efektu. Ekonomia złożoności postrzega tę zależność w sposób bardziej skomplikowany, nieliniowy: w kategorii efektu motyla. Dany bodziec powoduje długookresowy synergiczny i dynamiczny efekt, który rośnie nawet wtedy, gdy dany bodziec ulegnie zmniejszeniu. Może to doprowadzić do zmian nieodwracalnych w systemie lub do wprowadzenia go w stan chaosu [Jakimowicz, 2010].

Ekonomia złożoności zbliża się natomiast do ekonomii głównego nurtu (zwłaszcza najbardziej liberalnych odmian) stosunkiem do mikro- i makroekonomii. Zgodnie z jej podejściem cała makroekonomia jest rezultatem zachowań oraz interakcji między jednostkami występującymi na poziomie mikroekonomicznym, które wskutek emergentnych właściwości wywołują bardziej złożone zjawiska. Różnica między nurtami w tym aspekcie polega na tym, że ekonomiści złożoności przyjmują, iż poszczególne osobniki różnią się między sobą, nie są kolektywem, nie zawsze wykazują racjonalność czy egoizm, a więc ich decyzje są różnorodne, nie da się ich sprowadzić do modelu opartego na koncepcji zachowania racjonalnej jednostki. Aktorzy społeczni moga popełniać błędy, lecz również uczyć się i adaptować do zmiennych warunków otoczenia [Hommes, 2013].

To ostatnie wiąże się z koncepcją krawędzi chaosu [Krupski, 2010, s. 7-8]. Jest to pośredni stan układu, który znajduje się w wąskim obszarze między zachowaniem periodycznym a zachowaniem nieuporządkowanym. W stanie tym system potrafi sprostać wyzwaniom zmieniającego się otoczenia i jednocześnie oddalić niebezpieczeństwo rozpadu własnej struktury. W dynamicznych układach gospodarczych krawędź chaosu jest długookresowym atraktorem, a więc miejscem, do którego ostatecznie zmierza system. Prawidłowość ta została nazwana zasada postępującej złożoności. Obowiązuje ona zarówno na poziomie mikro, jak i na poziomie makro. Oznacza to, że obiekty ekonomiczne, niezależnie od szczebla, są złożonymi układa- 
mi adaptacyjnymi, a więc mają pewne zdolności do uczenia się i przystosowywania się do zmiennego otoczenia.

Odmienne w obu nurtach jest podejście do modelowania. W ekonomii złożoności przyjmuje się, że znaczący wpływ na gospodarkę mają jej stany w poprzednich okresach - bez znajomości historii nie da się przewidzieć dominujących trendów. Systemy gospodarcze są więc dynamiczne (zmienne w czasie i zależne od stanów początkowych) oraz heterogeniczne (różne oczekiwania, poziomy wiedzy i reakcje podmiotów na działania innych, co przekłada się na zróżnicowanie zachowań podmiotów), a więc moga mieć więcej niż jeden punkt równowagi, w dodatku może to być równowaga niestabilna. Ponadto dla pewnych wartości parametrów układu dochodzi do zachowań chaotycznych, których nie da się przewidzieć. Maksymalny rząd długości prognozy kształtowania się różnych zmiennych (np. PKB czy inflacji i bezrobocia), która ma sens - jest skuteczna - wskazuje czas Lapunowa, a więc czas, w granicach którego możliwe jest precyzyjne przewidywanie trajektorii danego procesu. Po jego upływie system popada w chaos, co uniemożliwia trafna prognozę, a przynajmniej mocno ogranicza prawdopodobieństwo, że będzie ona trafna [Jakimowicz, 2011, s. 44-49]. Złożoność otaczającego nas świata jest zbyt duża, by tradycyjne modelowanie mogło dać dobre rezultaty. Pozornie mało znaczące wydarzenia wspólnie moga spowodować zmianę kierunku ścieżki rozwoju danego produktu czy aktywności gospodarczej. Drobna zmiana może zapoczątkować zmianę trajektorii na prowadzącą do innego punktu równowagi. Proste modelowanie ekonomiczne jest zatem dopuszczalne tylko w ograniczonym zakresie i ma zastosowanie do prognozowania możliwie najmniej złożonych zjawisk. Przyszłością modelowania jest modelowanie systemów dynamicznych: przecinających się wzajemnie hierarchicznych układów o skomplikowanych interakcjach i nieustannie wyłaniających się nowych właściwościach będących efektem procesów adaptacji i uczenia się wewnątrz systemu. W tym sensie ekonomia złożoności nie tyle neguje ekonomię głównego nurtu, ile stanowi propozycję jej rewizji i uzupełnienia.

„Najistotniejsze elementy modeli złożonych to: 1) całościowe zachowanie bierze się z interakcji między jednostkami i nie można go przewidzieć, przyglądając się jednostce w izolacji; 2) owe systemy samoczynnie się organizują, jednak nigdy nie mogą utrzymywać się w „równowadze”, ponieważ nieustannie się zmieniają; 3) w ramach systemu jednostki mogą zachowywać się dość prosto i dlatego to ich wzajemne interakcje kształtuja złożone zachowania całościowe; 4) bezpośrednia interakcja między jednostkami jest głównym i definiującym elementem”. Ponadto „w gospodarce, w której przyszłość jest niepewna, istotną rolę odgrywają przewidywania jednostek (...). Istnieje mnóstwo dowodów na to, że ludzie nie maja tych samych oczekiwań. Co gorsza, ich oczekiwania nie są od siebie niezależne, a raczej silnie na siebie wpływają" [Kirman, 2018, s. 168], co może wprawiać system w chaos (np. przez pojawianie się baniek spekulacyjnych wskutek wzajemnego naśladowania się), ale może też prowadzić do trwałego funkcjonowania na krawędzi chaosu. 


\section{Interpretacja zjawisk towarzyszących pandemii COVID-19}

Spróbujmy ująć kwestię pandemii COVID-19, która rozpoczęła się na początku 2020 w Chinach i rozprzestrzeniła się na cały świat, z perspektywy ekonomii złożoności. Pierwsza myśl, która się narzuca, jest taka, że zjawisko to należało interpretować w kategoriach efektu motyla, a więc przekroczenia czasu Lapunowa, gdy precyzyjne przewidywanie i zapobieganie problemom staje się niemożliwe ze względu na rosnącą niestabilność i chaos. W tym przypadku czynnikiem zaburzającym funkcjonowanie systemu gospodarczego stał się wirus SARS Cov2. Jego skutkiem jest zmiana zachowań podmiotów rynkowych i kształtowanie się nowego porządku. Jest to więc zmiana początkująca podążanie gospodarki w stronę nowego punktu równowagi wynikającego z faktu, że reakcje jednostek na dokonujące się zmiany sa różnorodne. M. Mitchell [2020] w tym kontekście pisze o trzech analogiach, które mają nadać sens temu, co się wydarzyło, i zarazem stanowia podstawę podejmowanych decyzji: analogię wojny, kataklizmu lub grypy. K. Safarzyńska [2020] dodaje do tego analogię apokalipsy. Ci, którzy postrzegają koronawirus przez pryzmat grypy, są najmniej skłonni do zmiany swoich zachowań. Bagatelizują oni zagrożenie, zapominając, że koronawirus jest bardziej groźny od zwykłej grypy chociażby tylko z prostego powodu, że jest nowy i nie mamy jeszcze na niego odporności. Ta grupa ludzi z niechęcią traktuje związane z pandemią ograniczenia, a nawet je sabotuje. Druga strategia, porównywanie wirusa do kataklizmów naturalnych, prowadzi konsumentów do panicznych zakupów. Analogia wojny pomaga zaś usprawiedliwiać polityki, dla których w normalnych czasach nie znaleźlibyśmy akceptacji. Ta grupa podmiotów akceptuje surowe rygory polityki zwalczania pandemii. Analogia apokalipsy obejmuje zarówno oczekiwanie końca świata, jak i nadzieje na zmianę porządku społeczno-ekonomicznego lub romantyczne wizje uduchowienia ludzkości wobec tego „uniwersalnego” doświadczenia. Oznacza to gotowość do radykalnych zmian priorytetów gospodarczych i chęć rozwiązania przy okazji walki z pandemią problemów środowiskowych i społecznych, zwracając się w stronę trwałego i zrównoważonego rozwoju. Zarazem część podmiotów przyjmuje postawę pesymistyczna: niektóre podmioty gospodarcze przestaja prowadzić działalność gospodarczą, a konsumenci ograniczają konsumpcję, starając się oszczędzać środki finansowe na trudne czasy.

Wynika z tego, że to zróżnicowanie podejść jednostek należało uwzględnić w strategii walki z koronawirusem zamiast traktować społeczeństwo jak bierną „czarną skrzynkę", której zachowanie można precyzyjnie kontrolować, co stało się podstawa prowadzonej polityki w czasach COVID-19. Należało raczej przyjąć, że ludzie będą różnorodnie reagować - jedni będą akceptować pandemiczne ograniczenia i domagać się gruntownej zmiany gospodarki, inni będą ograniczenia sabotować. Część konsumentów ograniczy zakupy, część zwiększy. Część producentów zrezygnuje z aktywności gospodarczej, lecz inni zaczną poszukiwać bardziej kreatywnych rozwiązań pozwalających przetrwać rygory związane z pandemicznymi ograniczeniami, a nawet będą starać się wykorzystać sytuację do ekspansji na rynku. 
Pandemia sprawiła tė̇, że pojawiły się zmienne komplikujące prognozy gospodarcze, a przynajmniej mocno ograniczające ich precyzję, względnie być może nawet je uniemożliwiające. Złożone zmiany wymagają złożonej metodyki prognozowania, uwzględniającej różnorodne postawy, przewidywania, a więc i decyzje jednostek oraz perspektywę dynamiczną (historyczna). Tym główny nurt nie dysponuje. Natomiast ekonomia złożoności ją ma. Wystarczyło więc zastosować tę metodykę właśnie do przypadku COVID-19, a prawdopodobieństwo przewidzenia rozwoju wydarzeń i ich konsekwencji dla gospodarki wzrosłoby, można byłoby więc prowadzić sprawniejszą i bardziej akceptowalną politykę, uwzględniającą chaos wynikający z reakcji systemu społeczno-gospodarczego na pandemię, zróżnicowanie postaw jednostek oraz pozwalający na trafniejsze prognozy odnośnie do przyszłych zmian w poszczególnych branżach gospodarki oraz w procesach konsumpcji. Nowe zmienne to między innymi, oprócz zmienionych postaw producentów i konsumentów, zwłaszcza: opóźnienia w łańcuchach dostaw, zwiększone ryzyko kredytowe związane z zagrożeniem upadku przedsiębiorstwa lub utratą pracy, spadki notowań giełdowych, wzrost inflacji spowodowany przez keynesowsko nastawiona politykę państwa.

Potencjalną strategię działania wykorzystująca podejście ekonomii złożoności można określić jako próbę przywrócenia gospodarki do funkcjonowania na krawędzi chaosu. Można było ewentualnie starać się budować gospodarkę przygotowaną na wstrząs pandemiczny, wystarczyło przyjąć, że pandemia wywoła efekt motyla. Warto zaznaczyć, że pandemia rozprzestrzeniała się co prawda szybko, ale nie tak szybko, by państwa dały się zaskoczyć i nie podjęły praktycznie żadnych środków prewencyjnych, jak to miało miejsce w 2020 roku.

Autor sądzi, że działania moga być oparte na następujących elementach procesu decyzyjnego:

1. wyborze pomiędzy niezbędnym ustrukturyzowaniem procesów gospodarczych (utrzymywanie dobrego stanu instytucji, względnie dobrej kondycji finansowej przedsiębiorstw i gospodarstw domowych) a kreatywnością będącą zbiorem twórczych reakcji na pandemię prowadzącą do zmian w funkcjonowaniu gospodarki (np. zmiany organizacyjne, nowe zachowania konsumenckie itp.),

2. tworzeniu synergii pomiędzy poszczególnymi procesami i działalnościami, między innymi koordynacją działań przeciwstawiających się skutkom pandemii w wymiarze politycznym, organizacyjnym i przestrzennym,

3. nauce $z$ przeszłości: wyborze między rozwiązaniami nowatorskimi w walce z pandemia a poleganiem na sprawdzonych wzorcach wykorzystywanych w walce $z$ poprzednimi epidemiami,

4. planowaniu: wyborze między ścisłym określeniem reguł walki z pandemią i jej skutkami a określeniem jedynie ogólnych zasad dających szansę jednostkom na zachowania kreatywne (innowacyjne); jedną z szans mogłoby być wykorzystanie instrumentów ekonomii behawioralnej,

5. rytmie zmian - opisie tempa i procesów związanych z walką z COVID-19 i jego skutkami, 
6. wdrażaniu strategii walki z pandemią2.

Przede wszystkim jednak przyjmując, że pandemia najpewniej spowoduje przechodzenie gospodarki od „starego” do „nowego” stanu równowagi, należało przyjąć, że gospodarka postpandemiczna będzie już zmodyfikowanym systemem ekonomicznym. Grozi to tym, że niektóre „zamrożone” branże gospodarcze nie poradzą sobie w nowych uwarunkowaniach. Realne polityki zamiast próbować utrwalać stan dotychczasowy, powinny raczej oprzeć się na założeniu, że gospodarka się zmieni oraz, jak wspomniano, skupi się na konstruowaniu maksymalnie precyzyjnych modeli jej rozwoju w przyszłości wykorzystujących bardzo zaawansowane metody stochastyczne. Dałoby to bardziej wiarygodna prognozę rozwoju gospodarki, więc ułatwiłoby politykę aktywną: wspierająca zmiany pożądane i hamująca negatywne skutki kryzysu wybranych branż.

Podjęto jednak politykę opartą na głównonurtowym podejściu - ahistorycznym oraz indywidualistycznym, bazującym na idei bomo oeconomicus - starając się ,zahibernować" gospodarkę, pobudzać konsumpcję (co jednak, jak wskazano, jest skuteczne jedynie w przypadku części konsumentów, a równocześnie grozi pojawieniem się wysokiej stopy inflacji) oraz za pomocą nakazów i zakazów zmuszać jednostki do zachowań racjonalnych bez uwzględnienia różnorodności ich przewidywań i postaw. Rzeczywistość gospodarcza, społeczna, polityczna sa jednak zbyt skomplikowane, by tak zdyscyplinowane zachowania były skuteczne i powszechnie pozytywnie odbierane. W praktyce państwa, pojedynczy przedsiębiorcy i konsumenci obserwują się nawzajem, powielaja pewne rozwiązania, czasem poszukują innych alternatyw, próbując dopasować politykę do wewnętrznych uwarunkowań i do priorytetów konkurencyjnych, a więc zachowują się zgodnie z przewidywaniami ekonomistów złożoności. To pogłębia obecny chaos - sąsiadujące ze sobą kraje stosują odmienne strategie działania, nieograniczony przepływ informacji potęguje ryzyko i niepewność dodatkowo różnicując podejście przedsiębiorców i konsumentów do problemu, które coraz częściej staje się irracjonalne, względnie przesuwające się w stronę „szarej strefy”, czego jednak w polityce nie przewidziano. Zaowocowało to zaostrzaniem nakazów, coraz bardziej negatywnie ocenianych. W warunkach dominacji doraźnego i pragmatycznego mainstreamowego podejścia możliwe było właściwie tylko to, co się właśnie dzieje: bezradne obserwowanie kolejnych procesów przy stosowaniu chaotycznych i nieskoordynowanych rozwiazań trudnych do logicznego wyjaśnienia, a przez to niechętnie akceptowanych. Reakcje w sferze makroekonomicznej są nieadekwatne do zmian na poziomie mikro, dlatego nie mogą być wystarczająco skuteczne.

Jeśli zatem pandemia jest przechodzeniem od „starego” do „nowego” stanu równowagi, raczej krytycznie należałoby ocenić pomysły „zamrażania” gospodarki w formie, która miała ona przed nadejściem pandemii. Gospodarka postpandemiczna będzie już zmodyfikowanym systemem ekonomicznym, co grozi tym, że niektóre „zamrożone” branże gospodarcze nie poradzą sobie w nowych uwarunko-

\footnotetext{
2 Autor, konstruując model polityki walki z pandemia, wykorzystał elementy modelu organizacji działającej na krawędzi chaosu zaproponowany przez Browna i Eisenhardta [1998].
} 
waniach. Realne polityki próbują jednak utrwalać stan, od którego podmioty rynkowe już odchodzą, ponieważ ich przewidywania dotyczące przyszłości się zmieniły, co nie rokuje dobrze, jeśli chodzi o przyszłość gospodarki. Ekonomia złożoności wskazuje, że raczej należałoby założyć zmianę gospodarki i starać się konstruować maksymalnie precyzyjne modele jej rozwoju w przyszłości wykorzystujące bardzo zaawansowane metody stochastyczne. Dałoby to wiarygodna prognozę rozwoju gospodarki, więc ułatwiłoby politykę aktywną: wspierającą zmiany pożądane i hamującą negatywne skutki kryzysu wybranych branż.

Warto przytoczyć uwagę H. Daly'ego [1993], reprezentanta ekonomii ekologicznej zaliczanej, jak wskazano, przez ekonomistów złożoności do jednej z płaszczyzn analiz prowadzonych w ramach tego nurtu, że ekonomia głównego nurtu ma się do ekonomii złożoności jak fizyka mechanistyczna do nowej fizyki. Jest przypadkiem szczególnym, funkcjonującym prawidłowo wyłącznie w stabilnych, dalekich od granic warunkach. W sytuacjach granicznych się nie sprawdza, ponieważ opiera się na podejściu liniowym, ahistorycznym i reaktywnym. Wydaje się, że tak właśnie dzieje się w czasie obecnej pandemii COVID-19. Zastosowanie ekonomii złożoności z jej podejściem historycznym, długookresowym, nieliniowym i ewolucyjnym, akcentującym kwestię adaptacji do otoczenia, dałoby lepsze rezultaty, zapewniając skuteczniejszą politykę.

\section{Ekonomia złożoności w kontekście wybranych poglądów na problem pandemii}

O nieuchronności zmian w gospodarce, a tym samym w samej nauce ekonomii przekonanych jest coraz więcej ekonomistów, także niezwiązanych z ekonomią złożoności. Przykładowo Alves i Kvangraven [2020, s. 149-162] w takim kontekście piszą o konieczności zmiany narracji w naukach ekonomicznych. Starają się wykazać, że sytuacja pandemiczna obnażyła fundamentalne braki ekonomii głównego nurtu i związanego $z$ nia paradygmatu gospodarczego. Po pierwsze zmatematyzowana ilościowa ekonomia traktuje gospodarkę, społeczeństwo i środowisko jako odrębne sfery rzeczywistości. Stąd bierze się przekonanie o zewnętrzności pandemii wobec samej gospodarki. Ekonomiści głównego nurtu nie biorą pod uwagę, że gdyby nie globalne powiązania gospodarcze, logistyczne i transportowe, pandemia nie rozprzestrzeniłaby się w takim tempie. Po drugie paradygmat wolnego rynku sprawił, że ekonomia stała się nauką o efektywności, a nie o trwałym gospodarowaniu. Idea gospodarki jako ekspansywnego permanentnie rozrastającego się systemu odsunęła na daleki plan koncepcje gospodarki jako systemu adaptującego się do zmiennych potrzeb społecznych i uwarunkowań środowiskowych. Po trzecie przywiązanie do rozwiązań wolnorynkowych i idei homo oeconomicus spowodowało, że polityka walki z pandemia jest skupiona na rozwiązaniach administracyjno-nakazowych, przymuszających do zachowań racjonalnych przy niemal całkowitym zignorowaniu rozwiązań opartych na poczuciu ludzkiej sprawczości, społecznych inicjatywach oraz idei wspólnotowości. W opinii autorek niezbędne są zatem radykalna zmiana 
podejścia i zwrot ku ekonomii alternatywnej (heterodoksyjnej) [szerzej o tej ostatniej: Kiełczewski, 2020]. „Nacisk na ekonomię heterodoksyjna jako »historyczny proces zaopatrzenia społecznego« doprowadził do skupienia się na strukturach produkcji i reprodukcji w społeczeństwie, $\mathrm{z}$ ich historycznymi determinantami i mechanizmami przyczynowymi nie ograniczonymi do sfery rynku. Taka perspektywa może na przykład otworzyć drzwi do owocnych spostrzeżeń na temat dynamiki gospodarstw domowych w czasie kryzysu oraz ich relacji zarówno do produkcji, jak i reprodukcji. Inną konsekwencją tego poglądu jest to, że nie możemy oczekiwać takich samych reakcji behawioralnych lub wyników społecznych w różnych społecznościach, biorąc pod uwagę różnice w historii, kulturze i organizacji gospodarczej. Zamiast tego perspektywa zmusza nas do rozważenia, w jaki sposób na reakcje na pandemię wpływaja czynniki instytucjonalne, społeczne i ekonomiczne. Umiejscowienie gospodarki w społeczeństwie umożliwia eksplorację zawiłości między gospodarką a przyroda, np. przez badaczy systemów żywnościowych czy ekonomistów ekologicznych. Rzeczywiście, dla uczonych z szerszym zrozumieniem wpływu produkcji na żywność i systemy ekologiczne wzrost i rozprzestrzenianie się COVID-19 było mniejszym zaskoczeniem. Taka perspektywa wyraźnie kontrastuje z postrzeganiem pandemii jako egzogennego szoku. Dlatego teraz nadszedł czas, aby podkreślić, że produkcja kapitalistyczna przeplata się z naturą i nie może być postrzegana jako odrębna" [Alves, Kvangraven, 2020, s. 151].

Polscy autorzy [Banaszyk i in., 2021, s. 53-85], starając się przewidzieć zmiany w praktyce i teorii gospodarowania, uważają że pojawią się następujące tendencje:

a) wzrost popularności ekonomii heterodoksyjnej i akceptacja normatywnego wymiaru ekonomii,

b) rewizja koncepcji homo oeconomicus w kierunku propozycji nowej ekonomii instytucjonalnej, akcentującej rolę oportunizmu w zachowaniach jednostek,

c) wzrost roli skutków działalności przedsiębiorstw dla ich interesariuszy w ocenie jej sprawności,

d) zmiana podejścia w ocenie konkurencyjności międzynarodowej i sposobów zarządzania łańcuchami dostaw,

e) stopniowe przezwyciężanie ograniczeń modelu równowagi ogólnej,

f) stopniowe odchodzenie od PKB jako hegemona wśród mierników rozwoju gospodarczego,

g) wzrost rangi ekonomii rozwoju zajmującej się problemami rozwojowymi krajów słabo rozwiniętych.

Oba przytoczone stanowiska (to bardzo charakterystyczne przykłady tonu dyskusji o wpływie pandemii na ekonomię) wydaja się potwierdzać słuszność perspektywy ekonomii złożoności. Oznaczałoby to zatem, że wykorzystanie jej metod prognostycznych byłoby szczególnie uzasadnione choćby w procesach decyzyjnych związanych $z$ unijnym i krajowymi programami odbudowy gospodarki po pandemii, które dokonują się obecnie. 


\section{Podsumowanie}

Można uznać, że przyjęcie perspektywy ekonomii złożoności w opisie zjawisk towarzyszących pandemii COVID-19 pozwala na bardziej wiarygodne wyjaśnienie problemów i ograniczeń dotychczasowej polityki walki z koronawirusem niż w przypadku ekonomii głównego nurtu. Podejście ekonomii złożoności może być podstawą do sformułowania strategii rozwoju gospodarki postpandemicznej skuteczniejszej niż obecne na ogół keynesowskie rozwiązania. Chodzi o to, że perspektywa pandemiczna jest długookresowa, uwzględnia złożoność struktury gospodarki i zachowań podmiotów rynkowych, a także jest metodycznie przygotowana do podejmowania nieliniowych wyzwań wynikających ze skomplikowanych relacji między gospodarką a środowiskiem. Podejście to daje szansę wykorzystania obecnego kryzysu do uruchomienia procesów rozwoju gospodarczego nie tylko prowadzących do przezwyciężenia obecnych problemów ekonomicznych, ale również bardziej adekwatnych do współczesnych wyzwań gospodarczych, ekologicznych i społecznych. Może więc skierować procesy gospodarcze w stronę zrównoważonego rozwoju. Jest też dobrym przyczynkiem do rewizji dotychczasowego dorobku nauk ekonomicznych w postaci uzupełnienia ich o perspektywę historyczna, systemową i dynamiczną uwzględniająca, jak to określił S. Czaja i inni [2012, s. 227], nieliniowe wyzwania przyszłości, w stosunku do których ekonomia głównego nurtu jest coraz bardziej bezradna.

\section{Literatura}

Alves C., Kvangraven I., 2020, Changing the narrative: economics after the COVID-19, „Review of Agrarian Studies”, vol. 10(1), pp. 147-163, DOI: 10.22004/ag.econ. 308093.

Banaszyk P., Deszczyński P., Gorynia M., Malaga K., 2021, Przesłanki modyfikacji wybranych koncepïi ekonomicznych na skutek pandemii COVID-19, „Gospodarka Narodowa", nr 1(305), s. 53-86, DOI: 10.33119/GN/132485.

Brown S., Eisenhardt K.M., 1998, Competing on the edge. Strategy as a structured chaos, Harvard Business School Press, Boston.

Czaja S., Becla A., Włodarczyk J., Poskrobko T., 2012, Wyzwania współczesnej ekonomii. Wybrane problemy, Wydawnictwo Difin, Warszawa.

Daly H., 1993, Steady-state economics urban opportunity, Island Press, Washington.

Hommes C., 2013, Behavioral Rationality and Heterogeneuos Expectations in Compex Economic System, Cambridge University Press, Cambridge.

Jakimowicz A., 2010, Źródła niestabilności struktur rynkowych, Wydawnictwo Naukowe PWN, Warszawa.

Jakimowicz A., 2011, Dynamika nieliniowa $w$ badaniach ekonomicznych, „Didactic of Mathematics", nr 8(12), s. 39-54.

Jakimowicz A., 2017, Nowa ekonomia. Systemy złożone i homo compositus, Wydawnictwo Naukowe PWN, Warszawa. 
Kiełczewski D., 2020, Mainstream economics versus heterodox economics - between dispute and dialogue, „Optimum. Economic Studies” nr 2(100), s. 121-131, DOI: 10.15290/ oes.2020.02.100.09.

Kirman A., 2018, Ekonomia żtożoności, [w]: Pomyśleć ekonomie od nowa, Hülsmann J.G, Young S. (red.), Wydawnictwo Heterodox, Poznań.

Krupski R., 2010, Istota $i$ krytyka koncepcji organizacii driałajacej na krawedri chaosu, „Prace Naukowe Wałbrzyskiej Wyższej Szkoły Zarządzania i Przedsiębiorczości”, nr 14(1), s. 5-12.

Leszek P., 2011, Problematyka wiedsy w naukach spotecznych: o jednym zpowodón zawodności ekonomii gtównego nurtu w myjaśnianiu rzeczymistości gospodarczej, [w:] Pod prad gtównego nurtu ekonomii, Machaj M. (red.), Instytut Ludwiga von Misesa, Wrocław, http: mises/pl/blog/2017/02/16/leszek-problematyka-wiedzy-w-naukach-społecznych/ [data dostępu: 15.05.2021].

Manson S.M., 2001, Simplifying complexity: a review of complexity theory, „Geoforum”, vol. 32(3), pp. 405-414, DOI: 10.1016/S0016-7185(00)00035-X.

Mantegna R.N., Stanley H.E., 2000, An introduction to econophysics - correlation and complexity in finance, Cambridge University Press, Cambridge.

Maryniak P., 2016, Ewolucja teorii ušyteczności, DOI: 10.2139/ssm.2862763, https:// papers.ssrn.com/sol3/papers.cfm?abstract_id=2862763 [data dostępu: 14.05. 2021].

Mitchell M., 2020, The analogies we live by are shaping our thoughts about our current situation, Santa Fe Institute, Santa Fe.

Orrell D., 2010, Economyths, Icon Books, London.

Rosser J.B., 2004, Complexity in economics, Edward Elgar, Cheltenham.

Rosser J.B., 2008, Debating the role of econophysics, „Nonlinear Dynamics Psychology and Life Sciences", vol. 12(3), pp. 311-323.

Safarzyńska K., 2020, Koronawirus a złożonośc: trayy lekcje z ekonomii, „Krytyka Polityczna", https://krytykapolityczna.pl/gospodarka/koronowirus-zlozonosc-lekcje-zekonomii/ [data dostępu: 14.05.2021]. 